REKOGNISI: Jurnal Pendidikan dan Kependidikan

ISSN 2527-5259 Vol.1 No.1 Desember 2016

\title{
PENGEMBANGAN MODUL MATEMATIKA BERBASIS MASALAH UNTUK MENINGKATKAN KEMAMPUAN PEMECAHAN MASALAH MATEMATIKA SISWA
}

\author{
Anita Nasution \\ FKIP Universitas Al-Wasliyah Labuhanbatu \\ Email: anitanasution382@gmail.com
}

\begin{abstract}
ABSTRAK
Penelitian ini bertujuan untuk mengetahui: (1) efektivitas modul matematika berbasis masalah untuk meningkatkan kemampuan pemecahan masalah matematik siswa SMA Negeri 1 Padangsidimpuan dan (2) mengetahui peningkatan kemampuan pemecahan masalah matematik siswa dengan menggunakan modul matematika berbasis masalah. Penelitian ini merupakan penelitian pengembangan dengan menggunakan modifikasi antara model pengembangan 4-D yang dikembangkan oleh Thiagarajan, Semmel dan Semmel. Penelitian ini ada emapt tahap yaitu pendefenisian, perancangan, pengembangan, dan penyebaran. Namun, pada tahap penyebaran dilakukan secara terbatas di sekolah mitra yang menjadi subjek penelitian. Subjek dalam penelitian ini adalah siswa kelas X SMA Negeri 1 Padangsidimpuan. Hasil uji pengembangan: (1) modul matematika berbasis masalah memenuhi kriteria kevalidan dengan predikat valid; (2) modul matematika berbasis masalah praktis berdasakan hasil revisi dari tim ahli atau validator dan hasil wawancara; (3) modul matematika berbasis masalah efektif digunakan berdasarkan hasil pengamatan pencapaian persentase waktu ideal, hasil tes kemampuan pemecahan masalah matematik memenuhi ketuntasan klasikal yaitu $\geq 85 \%$ dari subjek uji coba, dan dari hasil angket respon siswa dan (4) peningkatan kemampuan pemecahan masalah matematik siswa dengan menggunakan modul dari uji I ke ujicoba II dan memenuhi ketuntasan klasikal.
\end{abstract}

Kata kunci: kemampuan pemecahan masalah matematik, matematika berbasis masalah, pengembangan, modul 


\begin{abstract}
This study aims to determine firstly, the effectiveness of mathematics based problem module to increase mathematics problem solving ability of student SMA Negeri 1 Padangsidimpuan; secondly, to determine the increase in the ability problem solving student by using mathematics based problem module. This study is a research of development by using a modification of the 4-D model of development by Thiagarajan, Semmel and Semmel. This research such as, define, designs, develop and disseminate. In disseminate stage of mathematics based problem module, it is done limitedly at the partner schools which is the subject of research. Subjects in this study were students of tenth grade of SMA Negeri 1 Padangsidimpuan. Development of test results: (1) the mathematics based problem module based on the criteria of validity with valid predicate, (2) the practical mathematics based problem module based on the results of revision from the experts, the results of observations during the learning process, and interviews, (3) module is effectively used, based on the results of observations, the achievement percentage of ideal time, the results of the tests of mathematics problem solving ability after the learning by using this module completed as $\geq 85 \%$ from the test and based on the results of the students questionnaire, and (4) increasing in mathematics problem solving ability of students by using the module from the test to the second test and based on the classical completeness.
\end{abstract}

Key words: development, mathematics based problem module, mathematics problem solving ability

\title{
PENDAHULUAN
}

Undang-Undang Sistem Pendidikan Nasional Nomor 20 tahun 2003 menjelaskan bahwa fungsi pendidikan adalah mengembangkan kemampuan dan membentuk watak yang bermartabat dalam rangka mencerdaskan kehidupan bangsa, sedangkan tujuan dari pendidikan adalah mengembangkan potensi peserta didik agar menjadi manusia yang beriman dan bertakwa kepada Tuhan Yang Maha Esa, berakhlak mulia, sehat, berilmu, cakap, kreatif, mandiri, dan menjadi warga negara yang demokratis serta bertanggung jawab. Berdasarkan tujuan dan fungsi pendidikan tersebut, sistem pendidikan nasional harus mampu merancang sistem pendidikan yang dapat meningkatkan mutu pendidikan itu sendiri.

Salah satu mata pelajaran yang menjadi sorotan dalam dunia pendi-dikan yaitu matematika. Matematika merupakan salah satu ilmu yang dipelajari pada setiap jenjang pendi-dikan mulai dari tingkat Sekolah Dasar (SD), Sekolah Menengah Pertama (SMP), Sekolah Menengah Atas (SMA) sampai ke Perguruan Tinggi. Matematika juga dijadikan salah satu syarat dalam menentukan kelulusan siswa. Matematika juga merupakan pengetahuan dasar yang diperlukan untuk menunjang keberhasilan siswa dalam menempuh pendidikan yang lebih tinggi. Hal ini menunjukkan bahwa matematika memiliki peranan yang sangat penting dalam dunia pendidikan. 
Permendiknas No. 22 tahun 2006 tentang Standar Isi, tujuan pembelajaran matematika untuk satuan pendidikan dasar dan menengah yaitu agar siswa memiliki kemampuan sebagai berikut: (1) memahami konsep matematika, menjelaskan keterkaitan antar konsep dan mengaplikasikan konsep atau algoritma, secara luwes, akurat, efisien, dan tepat, dalam pemecahan masalah; (2) menggunakan penalaran pada pola dan sifat, melakukan manipulasi matematika dalam membuat generalisasi, menyusun bukti, atau menjelaskan gagasan dan pernyataan matematika; (3) memecahkan masalah yang meliputi kemampuan memahami masalah, merancang model matematika, menyelesaikan model dan menafsirkan solusi yang diperoleh; (4) mengkomunikasikan gagasan dengan simbol, tabel, diagram, atau media lain untuk memperjelas keadaan atau masalah dan (5) memiliki sikap menghargai kegunaan matematika dalam kehidupan, yaitu memiliki rasa ingin tahu, perhatian, dan minat dalam mempelajari matematika, serta sikap ulet dan percaya diri dalam pemecahan masalah.

Salah satu kemampuan yang ditekankan kurikulum dan National Council of Teachers of Mathematics (NCTM) adalah kemampuan pemecahan masalah. Pemecahan masalah merupakan proses menerapkan pengetahuan yang telah diperoleh sebelumnya ke dalam situasi baru yang belum dikenal. Pemecahan masalah merupakan tipe belajar yang paling tinggi dibandingkan dengan tipe belajar lainnya. Menurut Abdurrahman (2009:254) pemecahan masalah dipandang sebagai aplikasi dari konsep dan keterampilan, dimana dalam pemecahan masalah biasanya melibatkan beberapa kombinasi konsep dan keterampilan dalam suatu situasi yang baru. Kemampuan pemecahan masalah sangat penting artinya bagi siswa dan masa depannya.

Fakta dilapangan menunjukkan bahwa kemampuan pemecahan masalah siswa masih rendah, salah satunya berdasarkan hasil tes Programme for International Student Assessment (PISA). Indonesia adalah salah satu negara peserta PISA. Distribusi kemampuan matematika siswa dalam PISA adalah level 1 (sebanyak 49,7\% siswa), level 2 (25,9\%), level 3 (15,5\%), level 4 (6,6\%), dan level 5 - 6 (2,3\%). Pada level 1 ini siswa hanya mampu menyelesaikan persoalan matematika yang memerlukan satu langkah. Secara proporsional, dari setiap 100 siswa SMP di Indonesia hanya sekitar 3 siswa yang mencapai level 5 - 6 .

Hal tersebut terjadi karena di lapangan umumnya pembelajaran matematika di sekolah masih cenderung terfokus pada ketercapaian target materi menurut kurikulum atau buku ajar yang dipakai sebagai buku wajib, bukan pada pemahaman materi yang dipelajari. Hal ini mengakibatkan siswa cenderung hanya menghapal konsep-konsep matematika, tanpa memahami maksud dan isinya. Grifth dan Sline (dalam Somayasa, 2013: 2) juga menyatakan pembelajaran di kelas cenderung dikembangkan melalui suatu pola teori-contoh-latihan.

Disamping kemampuan pemecahan masalah, hal lain yang perlu untuk diperhatikan dalam kegiatan belajar mengajar adalah bahan ajar. Bahan ajar 
merupakan seperangkat materi yang disusun secara sistematis, baik tertulis maupun tidak tertulis yang memung-kinkan peserta didik untuk belajar. Sebagaimana yang dikemukakan Soegiranto (Arlitasari, dkk, 2010: 83) bahwa bahan ajar adalah bahan atau materi yang disusun oleh guru secara sistematis yang digunakan peserta didik (siswa) dalam pembelajaran.

Bahan ajar sangat penting artinya bagi guru dan siswa. Guru akan mengalami kesulitan dalam meningkatkan efektivitas pembelajaran jika tanpa disertai bahan ajar yang lengkap. Begitu pula bagi siswa, tanpa adanya bahan ajar siswa akan mengalami kesulitan dalam belajarnya.

Perkembangan model pembelajaran saat ini telah maju pesat, dari model yang memfokuskan pada teacher centered beralih ke arah student centered. Meskipun demikian tidak semua sekolah bisa melakukan proses pembelajaran yang student centered. Sistem pembelajaran student centered membutuhkan perubahan paradigma para pelaku pembelajaran baik guru maupun siswa. Guru berperan sebagai fasilitator dan motivator, sedangkan siswa berperan sebagai pelaku pembelajar aktif dan mandiri.

Praktik pembelajaran sehari-hari di sekolah masih mengalami persoalan dengan bahan ajar yang digunakan dalam pembelajaran yang tidak menuntut student centered. Bahan ajar yang digunakan masih minim dan dirancang untuk dipasarkan secara luas, gaya penulisan naratif tetapi tidak komunikatif, sangat padat, tidak memiliki mekanisme untuk mengumpulkan umpan balik dari pembaca.

Siswa masih menemui kesulitan untuk memahami kalimat-kalimat dalam bahan ajar (buku pegangan) yang digunakan. Indaryanti (dalam Puspita, 2014: 3) menyatakan buku pegangan siswa saat ini rata-rata hanya memuat konten berupa materi yang tidak dijabarkan secara jelas dan tidak disertai gambar sebagai penjelasan dari materi pembelajaran sehingga siswa tidak bisa secara mandiri menggunakan buku pegangan atau modul dalam pembelajaran. Oleh karena itu, pengembangan bahan ajar penting dilakukan oleh pendidik agar pembelajaran lebih efektif, efisien, dan tidak melenceng dari kompetensi yang akan dicapainya. Pemilihan bahan ajar dan pengemba-ngannya sepenuhnya diserahkan kepada guru sebagai tenaga profesional.

Salah satu bahan ajar yang dapat dikembangkan oleh guru sesuai dengan karakteristik siswa adalah bahan ajar cetakan berupa modul. Asyhar (2012: 154) menyatakan bahwa media berbasis cetakan adalah media yang paling tua dan paling banyak digunakan karena praktis dalam penggunaannya, tidak memerlukan peralatan paling khusus, relatif murah dan mudah di dapat. Keunggulan dan kelebihan modul ialah modul mempunyai self instruction yang memungkinkan siswa dapat belajar secara mandiri dan guru tidak lagi menjadi satu-satunya sumber belajar bagi siswa. Jadi guru diharapkan dapat mengembangkan modul sesuai kebutuhan siswa. 
Hasil observasi empiriks peneliti di lapangan, guru masih jarang mengembangkan modul sendiri dan bahkan tidak pernah, hal ini terjadi karena banyaknya bahan ajar yang siap pakai sehingga guru tidak wajib mengembangkan bahan ajar yang dapat digunakan. Tetapi tidak adanya modul, menyebabkan siswa dominan mendengarkan dan mencatat yang sekaligus menjadi salah satu faktor pembelajaran tidak aktif melibatkan siswa dalam proses kegiatan belajar mengajar.

Pembelajaran dengan menggunakan modul dapat membantu sekolah dalam mewujudkan pembelajaran yang berkualitas. Modul dapat memfasilitasi siswa lebih tertarik dalam belajar, peserta didik otomatis belajar bertolak dari prerequisites, dan dapat meningkatkan hasil belajar.

Matematika merupakan mata pelajaran yang bersifat abstrak, rumit dan seringkali siswa sulit untuk memahaminya ataupun pendidik sulit untuk menjelaskannya. Adanya modul akan membantu siswa dalam menggambarkan sesuatu yang abstrak tersebut, misalnya dengan penggunaan gambar, foto, bagan, skema dan yang lainnya. Demikian pula materi yang rumit, dapat dijelaskan dengan cara yang sederhana, sesuai dengan tingkat berfikir peserta didik, sehingga menjadi lebih mudah dipahami.

Modul adalah materi yang harus dipelajari siswa sebagai sarana untuk mencapai kompetensi dan kompetensi dasar. Sebagaimana dengan pendapat Mukhtar (2013: 6) yang menyatakan bahwa bahan ajar sebagai hal-hal yang perlu dipelajari oleh siswa sebagai alat yang disediakan oleh pengajar untuk mencapai tujuan yang dikehendaki.

Berbagai masalah yang ada, peningkatan mutu pendidikan menjadi salah satu hal yang diprioritaskan oleh pemerintah. Keadaan ini telah mendorong untuk melakukan upaya perbaikan dalam bidang pendidikan. Terlihat dari Peraturan Menteri Pendidikan Nasional (Permendiknas) nomor 41 tahun 2007 tentang Standar Proses, yang antara lain mengatur tentang perencanaan proses pembelajaran, pelaksanaan proses pembelajaran, penilaian hasil pembelajaran, dan pengawasan proses pembelajaran.

Salah satu model pembelajaran yang telah berhasil meningkatkan aktivitas siswa selama kegiatan pembelajaran adalah model pembelajaran berbasis masalah. Melalui model pembelajaran berbasis masalah siswa diharapkan dapat mengkonstruksi pengetahuannya sendiri, mandiri dalam belajar, mampu mengkomunikasikan idenya, serta lebih termotivasi dalam memecahkan persoalan-persoalan dengan dunia nyata sehingga dengan demikian kemampuan pemecahan masalah matematik siswa juga akan semakin meningkat.

Pembelajaran berbasis masalah merupakan pembelajaran yang ditekankan dalam kurikulum sebagai tujuan untuk memberi pengetahuan kepada peserta didik melalui masalah nyata. Sejalan dengan Kunandar (2010: 354) yang menyatakan bahwa Problem Based Learning (PBL) merupakan suatu pendekatan pembelajaran yang menggunakan masalah dunia nyata sebagai suatu konteks bagi siswa untuk 
belajar tentang cara berpikir kritis dan keterampilan pemecahan masalah serta untuk memperoleh pengetahuan dan konsep yang esensial dari materi pelajaran. Senada dengan Trianto (2009: 94) yang menyatakan bahwa pembelajaran berdasarkan masalah memiliki tujuan: (1) membantu siswa mengembangkan keterampilan berpikir dan keterampilan pemecahan masalah; (2) belajar peranan orang dewasa yang otentik; dan (3) menjadi pembelajar yang mandiri.

Pembelajaran yang diterapkan hendaknya sesuai dengan bahan ajar yang digunakan. Kenyataannya di lapangan menunjukkan bahwa guru belum pernah mengembangkan modul matematika berbasis masalah khususnya di SMAN 1 Padangsidimpuan. Sehingga siswa seringkali kesulitan dalam memecahkan suatu persoalan apabila soal tersebut berbeda dengan apa yang diberikan, ini disebabkan karena guru tidak memberikan kesempatan kepada siswa untuk bekerja/mengkonstruksi pengetahuan siswa sesuai dengan masalah dunia nyata.

Penerapan modul berbasis masalah memberikan harapan untuk meningkatkan hasil belajar matematika siswa. Beberapa penelitian yang dilakukan menunjukkan bahwa hasil belajar siswa dengan menggunakan model pembelajaran berbasis masalah lebih baik daripada hasil belajar siswa yang menggunakan pembelajaran biasa. Sesuai dengan penelitian Minarni (2013: 10) menyatakan bahwa pendekatan pembelajaran berbasis masalah memberikan pengaruh lebih baik terhadap capaian kemampuan pemahaman matematik siswa dibandingkan pembelajaran biasa dan keterampilan sosial siswa yang mendapat pendekatan pembelajaran berbasis masalah lebih baik daripada siswa yang mendapat pembelajaran biasa. Hal ini juga diharapkan dapat terjadi jika model pembelajaran berbasis masalah diterapkan pada siswa SMA.

Berdasarkan uraian di atas, permasalahan yang akan dikaji dalam penelitian ini adalah bagaimana: (1) efektifitas modul matematika berbasis masalah yang dikembangkan untuk meningkatkan kemampuan pemecahan masalah matematik siswa SMA Negeri 1 Padangsidimpuan; (2) peningkatan kemampuan pemecahan masalah matematik siswa SMA Negeri 1 Padangsidimpuan dengan menggunakan modul matematika berbasis masalah. Sejalan dengan rumusan masalah tersebut, tujuan peelitian ini untuk mengetahui: (1) efektifitas modul matematika berbasis masalah yang dikembangkan untuk meningkatkan kemampuan pemecahan masalah matematik siswa SMA Negeri 1 Padangsidimpuan; (2) peningkatan kemampuan pemecahan masalah matematik siswa SMA Negeri 1 Padangsidimpuan dengan menggunakan modul matematika berbasis masalah.

\section{METODE PENELITIAN}

Jenis penelitian ini adalah penelitian pengembangan (Developmental Research) dengan menggunakan model pengembangan Thiagarajan Semmel dan Semmel yaitu model 4-D (define, design, develop, disseminate). 


\section{Subjek dan Objek Penelitian}

Subjek dalam penelitian ini adalah siswa kelas X SMA Negeri 1 Padangsidimpuan dan objek dalam penelitian ini adalah modul matematika berbasis masalah pada materi Trigonometri.

\section{Pengembangan Modul Matematika Berbasis Masalah}

Pengembangan modul matematika berbasis masalah dalam penelitian ini menggunakan model Thiagarajan, Semmel dan Semmel yaitu model 4-D (four $D$ models) yang terdiri dari 4 tahap, yaitu Define (pendefinisian), Design (desain), Develop (pengembangan), Disseminate (penyebaran). Tetapi dari model pengembangan Thiagarajan, Semmel dan Semmel pada penelitan ini yang diambil/dipakai sampai tahap penyebaran (disseminate) yang dilakukan pada uji coba terbatas pada kelas lain di sekolah yang sama.

Proses dan produk pembelajaran yang dikembangkan harus memenuhi kriteria valid, praktis dan efektif. Modul matematika dan komponen pembelajaran dikatakan valid jika modul matematika dan komponen pembelajaran didasarkan pada teori yang memadai dan berkaitan secara konsisten, dikatakan praktis jika ahli dan praktisi menyatakan bahwa secara teoritis modul matematika dapat diterapkan di lapangan serta respon siswa positif terhadap modul yang dikembangkan dan dikatakan efektif jika penggunaan modul matematika dapat mencapai tujuan yang dimaksud.

Analisis data validitas modul matematika dan komponen pembelajaran menggunakan analisis statistik deskriptif berdasarkan rata-rata skor dari masing perangkat pembelajaran yang telah divalidasi oleh validator/ahli dalam bidang pendidikan matematika dan direvisi berdasarkan koreksi serta saran para validator.

Kevalidan perangkat pembelajaran ini dilihat dengan menggunakan analisis statistik deskriptif berdasarkan rata-rata skor dari masing perangkat pembelajaran yang telah divalidasi. Kegiatan penentuan nilai rata-rata total aspek penilaian kevalidan mengikuti langkah-langkah berikut:

1. Melakukan rekapitulasi data penilaian kevalidan perangkat pembelajaran ke dalam tabel yang meliputi: aspek $\left(\mathrm{A}_{\mathrm{i}}\right)$, indikator $\left(\mathrm{I}_{\mathrm{i}}\right)$, dan nilai $\mathrm{V}_{\mathrm{ji}}$ untuk tiap-tiap ahli. Aspek-aspek ini dapat dilihat pada lembar validasi perangkat pada lampiran.

2. Menentukan rerata nilai dari ahli untuk setiap indikator dengan rumus:

$$
I_{i}=\frac{\sum_{j=1}^{n} V_{j i}}{n} \text { (Sinaga, 2007: 160) }
$$


Keterangan:

$\mathrm{V}_{j i}$ : data nilai dari penilai ke-j terhadap indikator ke- $I$,

$n$ : banyaknya penilai (ahli dan praktisi)

3. Menentukan rerata nilai untuk setiap aspek dengan rumus:

$A_{i}=\frac{\sum_{j=1}^{m} I_{i j}}{m}($ Sinaga, 2007: 160)

Keterangan:

$A_{i}$ : rerata nilai untuk aspek ke- $I$,

$\mathrm{I}_{i j}$ :rerata untuk aspek ke-i indikator ke-j,

$m$ : banyaknya indikator dalam aspek ke-I

4. Menentukan nilai Va atau nilai rerata total dari rerata nilai untuk semua aspek dengan rumus

$$
V a=\frac{\sum_{i=1}^{n} A_{i}}{n}(\text { Sinaga,2007: 160) }
$$

Keterangan :

$V a$ : nilai rerata total untuk semua aspek

$A_{i}$ : rerata nilai untuk aspek ke- $I$,

$n$ : banyaknya aspek

Selanjutnya nilai $V a$ atau nilai rerata total ini dirujuk pada interval penentuan tingkat kevalidan perangkat pembelajaran berbasis masalah yang dikembangkan, seperti ditunjukkan pada tabel 1.

Kriteria menyatakan perangkat pembelajaran yang dikembangkan memiliki derajat validitas yang baik, jika minimal tingkat validitas yang dicapai adalah tingkat valid. Jika tingkat pencapaian validitas di bawah valid, maka perlu dilakukan revisi berdasarkan masukan (koreksi) para ahli. Selanjutnya dilakukan kembali kegiatan validasi. Jika sudah dalam kategori valid, maka perangkat sudah layak diujicobakan ke lapangan.

Analisis data aktivitas siswa dilakukan dengan menghitung persentase pengamatan aktivitas siswa, yaitu:

Persentase Aktivitas Siswa $=\frac{\text { Frekuensi tiap Aspek }}{\text { Jumlah Frekuensi Semua Aspek }} \times 100 \%$

Batas toleransi dari waktu ideal yang diberikan adalah 5\%. Penentuan kriteria keefektifan aktivitas siswa berdasarkan pencapaian waktu ideal yang ditetapkan dalam penyusunan rencana pembelajaran berbasis masalah.

Respon siswa dianalis dengan menghitung persentase banyak siswa yang memberikan respon positif pada setiap kategori yang ditanyakan dalam angket. 
Kriteria yang ditetapkan untuk mengatakan bahwa para siswa memiliki respon yang positif terhadap modul matematika berbasis masalah yang dikembangkan adalah jika persentase banyak siswa yang memberi respon positif untuk setiap kategori atau aspek yang ditanyakan (PRS) $\geq 80 \%$.

Tabel 1. Kriteria Tingkat Kevalidan

\begin{tabular}{|l|l|l|}
\hline No & Va atau Nilai Rerata Total & Kriteria Kevalidan \\
\hline 1 & $1 \leq \mathrm{Va}<2$ & Tidak valid \\
\hline 2 & $2 \leq \mathrm{Va}<3$ & Kurang valid \\
\hline 3 & $3 \leq \mathrm{Va}<4$ & Cukup valid \\
\hline 4 & $4 \leq \mathrm{Va}<5$ & Valid \\
\hline 5 & $\mathrm{Va}=5$ & Sangat valid \\
\hline
\end{tabular}

Data kemampuan pemecahan masalah matematik siswa dianalisis untuk melihat ketuntasan belajar siswa. Adapun nilai ketuntasan kompetensi pengetahuan dan keterampilan dituang-kan dalam bentuk angka dan huruf, yakni 4,00 1,00 untuk angka yang ekuivalen dengan huruf A sampai dengan D. Ketuntasan belajar individu untuk pengetahuan ditetapkan dengan skor rerata 2,67.

Ketuntasan belajar per kelas (ketuntasan secara klasikal) atau PKK diperoleh dengan menghitung persen-tase banyak siswa yang tuntas secara individu. Persentasenya dapat dihitung dengan rumus:

$$
\mathrm{PKK}=\frac{\text { Banyak siswa yang tuntas belajar }}{\text { Banyak siswa keseluruhan }} \times 100 \%
$$

Suatu kelas dikatakan tuntas belajarnya jika PKK $\geq 85 \%$ (Trianto, 2011: 241).

\section{HASIL DAN PEMBAHASAN}

\section{Deskripsi Tahapan Pengembangan Modul Matematika Berbasis Masalah}

Tujuan penelitian adalah untuk mengembangkan modul matematika yang valid dan efektif dengan menggunakan model PBM. Secara rinci tahapan pengembangan modul matematika dijabarkan sebagai berikut:

a. Tahap Pendefinisian (define)

1. Analisis awal akhir

Fakta di lapangan menunjukkan bahwa guru belum mengembangkan modul yang sesuai dengan kondisi siswa. Buku pegangan yang digunakan memuat soal-soal kontekstual, sehingga siswa tidak menemukan sendiri konsepnya. Proses 
pembelajaran juga masih bersifat satu arah dimana guru berperan sebagai satusatunya sumber informasi yang menyampaikan pengetahuannya kepada siswa. Siswa cenderung pasif dalam kegiatan pembelajaran.

\section{Analisis siswa}

Hasil telaah karakteristik siswa SMA Negeri 1 Padangsidimpuan kelas X tahun ajaran 2014/2015 yaitu siswa kelas X SMA rata-rata berumur 15-16 tahun. Jika dikaitkan dengan tahap perkembangan kognitif menurut Piaget (Trianto,2011), maka siswa kelas X SMA berada pada tahap perkembangan operasional formal. Ciri pokok perkembangan pada tahap ini adalah anak sudah mampu berpikir abstrak dan logis. Oleh karena itu, sangat tepat jika pembelajaran matematika diawali dengan benda konkrit atau abstrak yang dekat dengan kehidupan mereka, sehingga diharapkan dapat membantu proses pemahaman siswa dan berpikir kritis matematis. Selanjutnya telaah terhadap latar belakang pengetahuan siswa diketahui telah mempelajari materi segitiga dan teorema pythagoras sebagai materi prasyarat untuk mempelajari materi trigonometri di SMA kelas X.

\section{Analisis konsep}

Hasil analisis konsep materi trigonometri mengacu pada KTSP, meliputi pengertian sudut, ukuran sudut (derajat dan radian), pengertian perbandingan trigonometri, perbandingan trigonometri pada segitiga siku-siku, perbandingan trigonometri pada sudut-sudut istimewa, perbandingan trigonometri di berbagai kuadran dan identitas trigonometri.

\section{Analisis tugas}

Hasil analisis tugas yang dilakukan adalah tugas-tugas yang dilakukan siswa pada saat pembelajaran dengan menggunakan modul pembelajaran yang dikembangkan, yaitu menemukan konsep sudut, menemukan ukuran sudut dalam derajat dan radian, menemukan perbandingan trigonometri pada segitiga siku-siku, menemukan konsep perbandingan trigonometri sudut-sudut istimewa, perbandingan trigonometri di berbagai kuadran dan menemukan konsep identitas trigonometri.

\section{Perumusan tujuan pembalajaran}

Hasil perumusan tujuan pembelajaran yang dilakukan disesuaikan dengan standar kompetensi dan kompetensi dasar KTSP.

a) Tahap Perancangan (Design)

1. Penyusunan tes

Tes yang digunakan adalah tes kemampuan pemecahan masalah matematik yang berbentuk uraian. 
2. Pemilihan media dan alat bantu

Media dan alat bantu pembelajaran yang digunakan adalah penggaris, kertas karton, gunting, pensil, pulpen, busur, gambar, kalkulator, dan penghapus.

3. Pemilihan format

Pemilihan format dilakukan dengan mengkaji format-format modul yang telah ada. Modul disusun dari beberapa literatur terkait materi trigonometri. Modul matematika berbasis masalah dibuat berwarna sehingga siswa akan tertarik dan termotivasi untuk belajar.

\section{Perancangan awal}

Pada tahap ini dihasilkan rancangan awal modul matematika berbasis masalah untuk meningkatkan kemampuan pemecahan masalah matematika siswa sesuai dengan karakteristik siswa. Modul yang dikembangkan memuat masalahmasalah kontekstual yang harus diselesaikan oleh siswa dan latihan mandiri. Hasil pada tahap perancangan ini disebut draf-I.

\section{b) Tahap Pengembangan (Develop)}

Hasil dari tahap define dan design menghasilkan rancangan awal sebuah modul pembelajaran yang disebut dengan draf I. Setelah modul matematika berbasis masalah di rancang dalam bentuk draf I, maka dilakukan uji validitas terhadap pakar/ahli (expert review) dan uji coba lapangan.

1) Hasil validasi ahli

Sebelum modul matematika berbasis masalah dan instrumen pene-litian diujicobakan, terlebih dahulu modul pembelajaran dan instrumen penelitian divalidasikan kepada lima orang validator yang termasuk pakar dalam bidangnya. Dari hasil validasi diperoleh untuk, 1) hasil validasi RPP yang divalidasi oleh tim ahli dengan rata-rata total 4,34 dengan kategori valid, 2) hasil validasi modul matematika berbasis masalah dengan rata-rata total 4,21 dengan kategori valid, 3) hasil validasi LKS dengan rata-rata total 4,50 dengan kategori valid, dan 4) validasi tes pemecahan masalah matematik siswa, dimana tim ahli menyatakan valid.

Selanjutnya, instrumen penelitian yaitu tes kemampuan pemecahan masalah matematik, terlebih dahulu diujicobakan pada kelas di luar sampel, kemudian dilakukan uji validitas dan reliabilitas.

2) Uji coba I

Setelah modul pembelajaran yang dikembangkan telah memenuhi kriteria valid. Selanjutnya modul pembelajaran dalam bentuk draf II ini diujicobakan di tempat penelitian yaitu uji coba I dilakukan di kelas X-5 SMA Negeri 1 Padangsidimpuan. 
a) Hasil kepraktisan

Modul matematika berbasis masalah (draf II) dikatakan praktis jika validator menyatakan bahwa:

(1) Modul dapat digunakan dengan sedikit revisi atau tanpa revisi.

(2) Angket respon positif siswa terhadap modul yang dikembangkan pada uji coba I berada di atas $80 \%$ yaitu $81,50 \%$ dan pada uji coba II $85,50 \%$. Itu artinya siswa memberikan respon yang baik terhadap modul yang dikembangkan.

b) Hasil keefektifan

Aktivitas siswa selama pembelajaran diberi keterangan:

1. Memperhatikan/mendengarkan penjelasan guru/teman.

2. Membaca/ memahami masalah kontekstual dalam modul matematika/ LKS.

3. Menyelesaikan masalah/menemukan cara dan jawaban dari masalah.

4. Berdiskusi/bertanya kepada teman atau guru.

5. Menarik kesimpulan suatu prosedur atau konsep dan menyajikan hasil karya.

6. Perilaku siswa yang tidak relevan dengan KBM.

Keefektifan modul dapat dilihat pada dominan penggunaan waktu selama belajar menggunakan modul. Rerata persentase waktu yang digunakan siswa dalam melakukan aktivitas selama penggunaan modul berbasis masalah dapat dilihat pada gambar 1 .

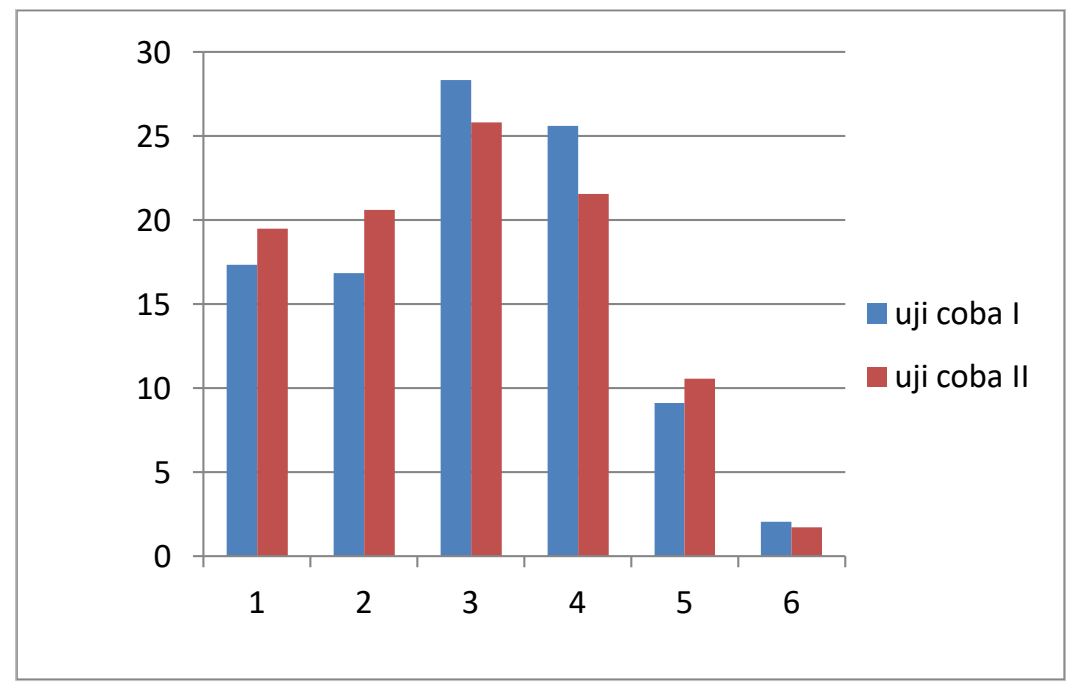

Gambar 1. Rerata Persentase Aktivitas Siswa

Gambar 1 menunjukkan persentase waktu terbesar yang digunakan siswa selama kegiatan belajar mengajar adalah kategori (3). Hal ini menunjukkan selama 
kegiatan pembelajaran, siswa lebih dominan menghabiskan waktu untuk memecahkan maupun menemukan penyelesaian masalah pada LKS.

Tujuan pembelajaran matematika berdasarkan indikator kemampuan pemecahan masalah, diberi keterangan:

1. Siswa mampu memahami masalah

2. Siswa merencanakan menyelesaian

3. Siswa mampu menyelesaikan masalah

4. Siswa mampu melakukan pemeriksaan

Rerata ketercapaian tujuan pem-belajaran untuk setiap indikator ditunjukkan dengan diagram batang. Diagram tersebut dapat dilihat pada gambar 2 .

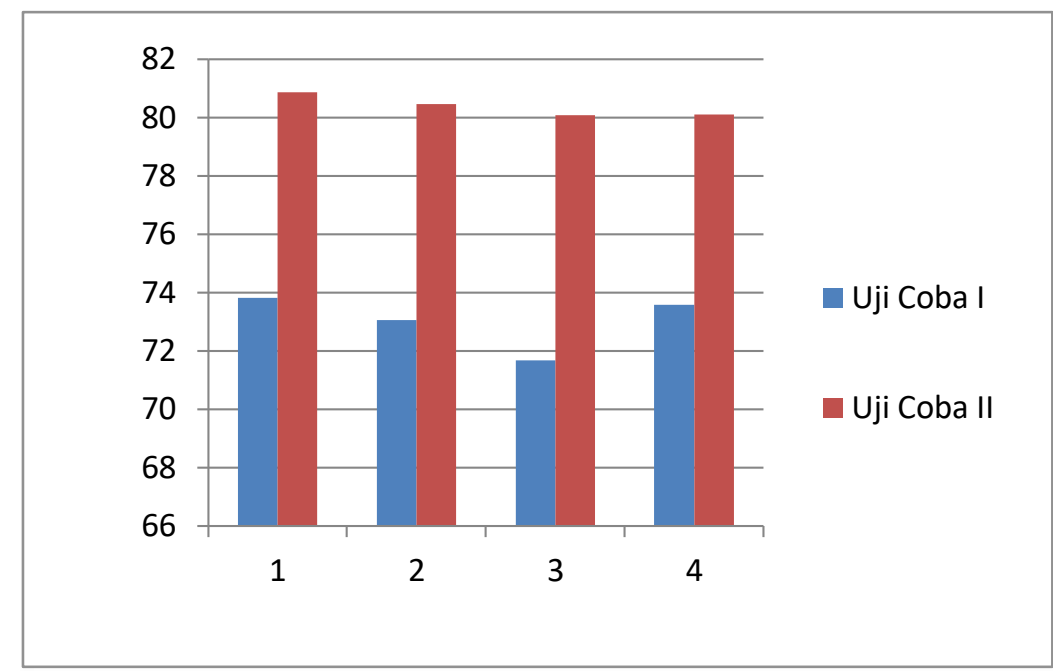

\section{Gambar 2. Hasil Ketercapaian Tujuan Pembelajaran}

Uji coba I ke uji coba II mengalami peningkatan dengan ketercapaian tujuan pembelajaran yaitu diatas $75 \%$. Hasil tes kemampuan pemecahan masalah matematik siswa disajikan pada tabel 2 .

Tabel 2. Jumlah Siswa yang Tuntas pada Uji Coba I dan Uji Coba II

\begin{tabular}{|l|c|c|}
\hline \multicolumn{1}{|c|}{ Ket } & $\begin{array}{c}\text { Uji Coba } \\
\text { I }\end{array}$ & $\begin{array}{c}\text { Uji Coba } \\
\text { II }\end{array}$ \\
\hline Siswa yang tuntas (\%) & 81,25 & 90,63 \\
\hline Siswa yang tidak tuntas (\%) & 18,75 & 9,37 \\
\hline
\end{tabular}

Pada tabel 2 terlihat bahwa pada uji coba I dari 32 orang siswa rerata ketuntasan klasikal 81,25\% dan rerata ketuntasan klasikal yang diperoleh dari uji 
coba II dengan subjek sebanyak 32 orang siswa adalah 90,63\%. Secara keseluruhan pencapaian ini telah memenuhi kriteria ketuntasan klasikal yaitu minimal $85 \%$ dari jumlah siswa tuntas dengan nilai paling kecil 2,67 dengan predikat B-. Berikut ini akan dijabarkan jumlah siswa yang mencapai ketuntasan untuk masing-masing pertemuan pada uji coba I dan uji coba II. Berdasarkan tabel 2 tersebut menunjukkan bahwa kemampuan pemecahan masalah matematik siswa menggunakan modul matematika berbasis masalah yang dikembangkan mengalami peningkatan dari ujicoba I ke ujicoba II.

c) Tahap Penyebaran (Diseminate)

Modul matematika berbasis masalah dalam penelitian ini dilakukan penyebaran secara terbatas hanya pada sekolah mitra saja dari materi, kelas/siswa dan waktu (penyebaran khusus). Setelah perangkat final, modul matematika berbasis masalah yang telah dikembangkan disebarkan untuk dapat digunakan pada semester berikutnya dalam materi trigonometri.

\section{Keefektifan Modul Pembelajaran}

Keefektifan modul matematika berbasis masalah dilihat dari tiga aspek yaitu (1) pencapaian persentase waktu ideal aktivitas siswa (2) ketercapaian tujuan pembelajaran, (3) ketuntasan kemampuan pemecahan masalah secara klasikal.

\section{Aktivitas Siswa}

Aktivitas siswa diukur dengan melakukan pengamatan kepada bebe-rapa siswa yang sudah mewakili kelompok siswa yang tinggi, sedang dan rendah. Pengamatan aktivitas siswa dilakukan selama proses penelitian berlangsung. Pada uji coba lapangan pertama dan kedua aktivitas siswa sudah berada pada katagori minimal keefektifan aktivitas siswa.

\section{Ketercapaian Tujuan Pembelajaran}

Ketercapain tujuan pembelajaran dikatakan tercapai dengan kriteria di atas 75\% dari skor maksimum. Dengan demikian ketercapaian tujuan pembelajaran pada hasil postes uji coba I adalah belum tercapai.

Pada uji coba II, berdasarkan kriteria pencapaian tujuan pada hasil postes uji coba II adalah sudah tercapai yaitu di atas $75 \%$.

\section{Ketuntasan kemampuan pemecahan masalah secara klasikal}

Pada uji coba lapangan pertama ketuntasan tes kemampuan pemecahan masalah matematik siswa masih berada di bawah 85\%. Sedangkan pada uji coba lapangan kedua, ketuntasan sudah mencapai pada kriteria ketuntasan klasikal yakni $90,63 \%$. 


\section{Peningkatan Kemampuan Pemecahan masalah Matematik}

Peningkatan kemampuan pemecahan masalah matematik siswa pada uji coba lapangan pertama yaitu 2,67 meningkat menjadi 2,94 pada uji coba lapangan kedua. Kemampuan pemecahan masalah matematika siswa mengalami peningkatan yang signifikan yakni sebesar 0,27 (6,75\%).

\section{SIMPULAN}

Pengembangan modul matematika berbasis masalah untuk meningkatkan kemampuan pemecahan masalah matematika siswa. Dari hasil penelitian yang telah dilakukan maka kesimpulan yang dapat diuraikan dalam penelitian ini adalah:

1. Proses modul matematika berbasis masalah dimulai dari tahapan define, design, develop dan desiminate. Dari tahapan design diperoleh sebuah modul matematika berbasis masalah (draf I). Selanjutnya masuk ke dalam tahapan develop dengan memvalidasi draf I kepada tim ahli sebanyak lima orang ahli kemudian dihasilkan draf II untuk di uji coba I setelah dilakukan revisi dilakukan uji coba II. Berdasarkan proses pengem-bangan diperoleh draft final yang memenuhi kriteria:

\section{a. Validitas}

Berdasarkan validasi tim ahli untuk, 1) hasil validasi RPP yang divalidasi oleh tim ahli dengan rata-rata total 4,34 dengan kategori valid, 2) hasil validasi modul matematika berbasis masalah dengan rata-rata total 4,21 dengan kategori valid, 3) hasil validasi LKS dengan rata-rata total 4,50 dengan kategori valid, dan 4) validasi tes pemecahan masalah matematik siswa, dimana tim ahli menyatakan valid.

\section{b. Kepraktisan}

Berdasarkan indikator keprak-tisan bahwa modul yang dikem-bangkan dapat digunakan dengan sedikit revisi atau tanpa revisi dan angket respon positif siswa terhadap penggunaan modul yang dikembangkan. Pada uji coba I rerata total respon positif siswa sebesar $81,50 \%$ sedangkan pada uji coba II rerata total respon positif siswa sebesar $85,50 \%$ sehingga kriteria ini tercapai.

c. Keefektifan

Berdasarkan indikator keefektifan yaitu: 1) Pencapaian persentase waktu ideal aktivitas siswa berada dalam pencapaian waktu ideal aktivitas siswa dengan toleransi waktu 5\%, (2) Ketercapaian tujuan pembelajaran yaitu $\geq 75 \%$ dari skor maksimum pada setiap butir, ketercapaian tujuan pada uji coba I untuk indikator pemecahan masalah dalam bentuk visual (gambar) hasil postes adalah sebesar 73,83\%, ketercapaian tujuan pembelajaran pada indikator pemecahan masalah yang diberikan ke dalam persamaan matematika hasil postes adalah sebesar 73,05\%, ketercapaian tujuan pembelajaran pada indikator pemecahan 
masalah, kembali masalah yang diberikan dalam bentuk kata atau teks tertulis hasil postes adalah sebesar $71,68 \%$. Artinya pada uji coba I tujuan pembelajaran belum tercapai. Tetapi pada uji coba II untuk indikator pemecahan masalah masalah dalam bentuk visual (gambar) hasil postes adalah sebesar 80,86\%, ketercapaian tujuan pembelajaran pada indikator pemecahan masalah yang diberikan ke dalam persamaan matematika hasil postes adalah sebesar 80,47\%, ketercapaian tujuan pembelajaran pada indikator pemecahan masalah, kembali masalah yang diberikan dalam bentuk kata atau teks tertulis hasil postes adalah sebesar 80,08\%. Artinya pada uji coba II tujuan pembelajaran telah tercapai; (2) ketuntasan klasikal yaitu $\geq 85 \%$ pada uji coba I dengan jumlah siswa 32 orang ketuntasan klasikalnya $81,25 \%$ dan pada uji coba II sebesar 90,63\% sehingga memenuhi kriteria ketuntasan klasikal.

2. Kemampuan pemecahan masalah matematik siswa mengalami peningkatan, hal ini terlihat dari persentase ketuntasan klasikal siswa pada ujicoba I sebesar 81,25\%, dan persentase ketuntasan klasikal siswa pada ujicoba II sebesar 90,63\%. Dengan kata lain, peningkatan pemecahan masalah matematik siswa dari ujicoba I ke ujicoba II mengalami peningkatan. 


\section{DAFTAR PUSTAKA}

Abdurrahman, M. 2009. Pendidikan bagi anak berkesulitan belajar. Jakarta: Rineka Cipta.

Artilasari, dkk. 2013. Pengembangan Bahan Ajar IPA Terpadu Berbasis Salingtemas dengan tema Biomassa Sumber Energi Alternatif Terbarukan. Jurnal Pendidikan Fisika 2013.Vol.1, No. 1: 81-91.

Asyhar, R. 2012. Kreatif Mengembangkan Media Pembelajaran. Jakarta: Referensi Jakarta.

Kunandar, 2010. Guru Profesional Implementasi Kurikulum Tingkat Satuan Pendidikan (KTSP) dan Sukses dalam Sertifikasi Guru. Jakarta: Rajawali Pers.

Minarni, A. 2013. Pengaruh Pembelajaran Berbasis Masalah Terhadap Kemampuan Pemahaman Matematis dan Keterampilan Sosial SMP Negeri Di Kota Bandung. Jurnal Pendidikan Matematika Paradikma, Volume 6, No. 2: 162-174.

Mukhtar, 2013. Pengembangan Bahan Ajar Matematika Berbasis Masalah untuk Memfasilitasi Pencapaian Kemampuan Pena-laran dan Pemahaman Konsep Siswa. Prosiding Semirata FMIPA Universitas Lampung, 2013.

National Council of Teachers of Mathematics. 2000. Principles and Standards for School Mathematics. United State: Nasional Council of Teachers of Mathematics, Inc.

Peraturan Menteri Pendidikan Nasional No. 41 tahun 2007 tentang Standar Proses. Jakarta: Menteri Pendidikan Nasional.

Peraturan Menteri Pendidikan Nasional No. 20 Tahun 2003 tentang Faktor Pendidikan Nasional. Jakarta: Menteri Pendidikan Nasional.

PISA 2012. 2013. Result in Focus, What 15-year-olds know and what they can do with what they know. OECD, Programme for International Student Assesment.

Puspita, M, dkk. 2014. Pengembangan Modul Bilingual Bergambar Terhadap Minat Belajar Siswa

Thiagarajan, S. Semmel, D.S. Semmel, M. 1974. Instructional Development for Training Teachers of Exceptional Children. A Sourse Book. Blomington: Central for Innovation on Teaching The Handicapped.

Trianto, 2009. Mendesaian Model Pembelajaran Inovatif-Progresif. Jakarta: Bumi Aksara. , 2011. Model Pembelajaran Terpadu. Jakarta: Bumi Aksara. 